\title{
WHAT'S WRONG WITH SELLING YOURSELF INTO SLAVERY? PATERNALISM AND DEEP AUTONOMY*
}

\author{
ANDREW SNEDDon \\ Philosophy Department \\ University of Calgary \\ asneddon@ucalgary.ca
}

Summary: Such thinkers as John Stuart Mill, Gerald Dworkin, and Richard Doerflinger have appealed to the value of freedom to explain both what is wrong with slavery and what is wrong with selling oneself into slavery. Practical ethicists, including Dworkin and Doerflinger, sometimes use selling oneself into slavery in analogies intended to illustrate justifiable forms of paternalism. I argue that these thinkers have misunderstood the moral problem with slavery. Instead of being a central value in itself, I argue that freedom is a means of serving the real value of autonomy. Moreover, I argue that autonomy is ambiguous. In cases of conflict, autonomous choice, here called "shallow autonomy", can justifiably be limited to serve "deep autonomy", or self-rule. I use these notions to give a better understanding of the problem with selling oneself into slavery, and argue that the work of Dworkin has to be seriously revised, and Doerflinger's position has to be given up altogether.

KEY wORDS: autonomy, freedom, Gerald Dworkin, John Stuart Mill, paternalism, Richard Doerflinger, slavery

Resumen: John Stuart Mill, Gerald Dworkin y Richard Doerflinger han recurrido al valor de la libertad para explicar tanto porque está mal moralmente la esclavitud como venderse uno mismo como esclavo. Los teóricos de la ética práctica, incluidos Dworkin y Doerflinger, a veces utilizan el caso de venderse uno mismo como esclavo en analogías que pretenden ilustrar formas justificables de paternalismo. Sostengo que estos pensadores han malinterpretado el problema moral con la esclavitud. Argumento que en lugar de ser un valor fundamental en sí mismo, la libertad es un medio para el valor real de la autonomía. Arguyo, por otra parte, que la autonomía es ambigua. En casos de conflicto, la elección autónoma, denominada aquí "autonomía superficial", puede justificadamente estar limitada a servir a la "autonomía profunda", o autogobierno. Utilizo estas nociones para ofrecer una mejor interpretación del problema moral con venderse uno mismo como esclavo, y sostengo que la obra de Dworkin se debe revisar con seriedad, y que se debe abandonar por completo la postura de Doerflinger.

Palabras Clave: autonomía, libertad, Gerald Dworkin, John Stuart Mill, paternalismo, Richard Doerflinger, esclavitud ments.

* Thanks to Stephen Clark and an anonymous referee for helpful com- 


\section{Introduction}

Practical ethicists occasionally appeal to the values involved with slavery to clarify the values central to other sorts of personal interaction. For example, Gerald Dworkin looks to our practices regarding slavery for guidance as to what sorts of paternalistic practices might be morally justifiable. ${ }^{l}$ In particular, Dworkin argues that since such paternalistic prohibitions as those against selling ourselves into slavery are justified, we can look to them to formulate a general principle of justified paternalism. Richard Doerflinger uses slavery in a more specific context. ${ }^{2} \mathrm{He}$ too points to prohibitions against selling ourselves into slavery. $\mathrm{He}$ also thinks such prohibitions are justified. He thinks such practices indicate a problem in the position of those who argue for physician-assisted suicide and euthanasia on the basis of the importance of freedom. In short, both Doerflinger and Dworkin are interested in slavery as a guide to when the state is justified in limiting free choice.

The purpose of this paper is to show that Doerflinger and Dworkin have misunderstood what is wrong with slavery, and hence what is wrong with selling oneself into slavery. The particular problem, no doubt shared by others, is treating freedom as the central value with regard to slavery. Instead, I will argue that autonomy and justice are the relevant values. This change of emphasis turns out to have deep implications for the justification of limitations on people's choices. In particular, the positions of both Dworkin and Doerflinger will be shown to be mistaken. ${ }^{3}$

1 G. Dworkin 1972.

${ }^{2}$ R. Doerflinger 1989.

3 An important qualification is warranted here. Both Dworkin and Doerflinger use slavery in passing. Consequently, they do not examine the phenomenon in detail. But slavery comes in many forms, and the term even seems to mean different things at different times in human history. It is reasonable to think that the differences in kinds of slavery bring with them different moral problems. Since I am following the lead of Dworkin and Doerflinger, I too will not look at various forms of slavery. Instead, I will be considering a rather rarefied, theoretical form of slavery, which I will characterize in due course. Nevertheless, I think this "philosophical" slavery is familiar, at least to North Americans, and it is certainly the sort of practice to which Dworkin and Doerflinger appeal. 


\section{The Positions of Dworkin and Doerflinger}

Gerald Dworkin formulates his principle of justified paternalism through an examination of John Stuart Mill's On Liberty. ${ }^{4}$ It is Mill who brings up slavery. Dworkin notes that Mill intends to oppose paternalism - i.e., interference with the free choice of others in the name of their own good but contrary to their wishes - entirely. Dworkin points out that Mill's case for this is not entirely utilitarian. The absolute prohibition of paternalism can only be made on deontological grounds. This is reasonable: the a posteriori spirit of utilitarianism should always be open to the possibility, to be determined on empirical grounds, that maximizing happiness would be better accomplished through limitations on freedom than through letting people choose freely. Hence Mill needs other conceptual resources to make his case. Interestingly, the deontological aspect of Mill's case comes out in a statement of agreement with a particular paternalistic practice: the prohibition on people selling themselves into slavery. Here is the relevant passage, also mostly quoted and discussed by Dworkin:

In this and most other civilized countries, for example, an engagement by which a person should sell himself, or allow himself to be sold, as a slave, would be null and void; neither enforced by law nor by opinion. The ground for thus limiting his power of voluntarily disposing of his own lot in life, is apparent, and is very clearly seen in this extreme case. The reason for not interfering, unless for the sake of others, with a person's voluntary acts, is consideration for his liberty. His voluntary choice is evidence that what he so chooses is desirable, or at least endurable, to him, and his good is on the whole best provided for by allowing him to take his own means of pursuing it. But by selling himself for a slave, he abdicates his liberty; he foregoes any future use of it beyond that single act. He therefore defeats, in his own case, the very purpose which is the justification of allowing him to dispose of himself. $\mathrm{He}$ is no longer free; but is thenceforth in a position which has no longer the presumption in its favor, that would be afforded by his voluntarily remaining in it. The principle of freedom cannot require that he should be free not to be free. It is not freedom,

\footnotetext{
4 J.S. Mill 1947.
} 
to be allowed to alienate his freedom. These reasons, the force of which is so conspicuous in this particular case, are evidently of far wider application. . ${ }^{5}$

Dworkin agrees with the spirit of Mill's argument and uses it to formulate a principle of justified paternalism:

But the main consideration for not allowing such a contract [i.e., to sell oneself into slavery] is the need to preserve the liberty of the person to make future choices. This gives us a principle - a very narrow one, by which to justify some paternalistic interferences. Paternalism is justified only to preserve a wider range of freedom for the individual in question. How far this principle could be extended, whether it can justify all the cases in which we are inclined upon reflection to think paternalistic measures justified remains to be discussed. ${ }^{6}$

Besides selling oneself into slavery, Dworkin thinks this principle accords with such paternalistic practices as, among others, motorcycle helmet laws, laws making it mandatory for people to wear seatbelts, and the putting of fluoride in public water supplies. All of these limitations on the freedom of people increase or preserve their likely range of future freedom.

For present purposes, the important thing to note about Dworkin's use of Mill's position is the value around which the discussion turns. Both Mill and Dworkin think that the value to be preserved, and to which to appeal when deciding whether certain sorts of paternalistic practice are justified, is freedom. I will call this idea into question in the next section.

Richard Doerflinger treats freedom similarly, but not in exactly the same way. Doerflinger argues against defenses of suicide and euthanasia that focus on freedom. ${ }^{7}$ There are influential

5 Ibid., p. 104.

6 Munson 2000, p. 407.

7 Daniel Callahan (1992) makes a similar appeal to slavery in an antieuthanasia argument ("When Self-Determination Runs Amok", pp. 52-55). Here is his use: "Slavery was long ago outlawed on the ground that one person should not have the right to own another, even with the other's permission. Why? Because it is a fundamental moral wrong for one person to give over 
arguments $^{8}$ in favor of euthanasia and physician-assisted suicide that cite freedom as a central rationale. Doerflinger thinks this is self-defeating - he sees death as the end of freedom, not an expression of it. To treat freedom as a genuine value requires that we limit those free acts that would destroy it. Doerflinger points to legal prohibitions against selling ourselves into slavery as exemplifying this rationale: "[...] society best serves freedom by discouraging rather than assisting self-destruction. Sometimes one must limit particular choices to safeguard freedom itself, as when American society chose over a century ago to prevent people from selling themselves into slavery even of their own volition." fying the right to choose freely to end one's life might claim that the successful suicide does not really lose freedom, insofar as s/he does not continue to exist in a state of diminished freedom. S/he does not exist at all. Doerflinger's answer charges the proponent of assisted suicide and euthanasia with an inconsistency: "To claim that a slave is worse off than a corpse is to value a situation of limited freedom less than one of no freedom whatsoever, which seems inconsistent with the premise of the "pro-choice' position." 10 In short, Doerflinger largely agrees with Dworkin's neo-Millian position: if one is going to treat freedom as a value, then one is forced to limit some present free choices in the name of preserving future freedom. In particular, the paternalistic measure that Doerflinger argues that the value of

his life and fate to another, whatever the good consequences..." (Soifer 1997, p. 410). Despite the fact that Callahan's paper is better known than Doerflinger's, I shall concentrate on the latter's use of slavery. The reason is that Doerflinger has more to say about the reason this is a moral wrong; Callahan does little more than assert that it is wrong.

${ }^{8}$ For example, see D. Brock 1992, pp. 10-22. Brock speaks in terms of self-determination, which is often interpreted in terms of freedom. More on this below.

9 Kluge 1999, p. 378.

10 Id. 
freedom justifies is laws against physicians helping patients die, and perhaps against suicide altogether. ${ }^{11}$

\section{Slavery}

Dworkin and Doerflinger appeal to slavery in very similar ways: they both think laws prohibiting us from selling ourselves into slavery are justified, and they take this to be a matter accounted for by appeal to the nature of freedom as a value. Are they correct? Answering this question requires looking at slavery anew.

If we were to ask people on the street what was wrong with slavery, I would expect two ideas to come up regularly. I would expect people to agree with Doerflinger and Dworkin that slavery has something to do with freedom. In particular, remedying the ills of slavery seems to be best accomplished by granting slaves their freedom. But I would also expect a second idea to come up, one that does not arise in the treatments of slavery by Dworkin, Doerflinger, and Mill. I would expect people on the street to say that slavery is somehow unjust. The idea that slavery is a problem of justice that has something to do with freedom, which I take to capture everyday intuitions about this matter, is accurate, but it needs to be developed. I am going to develop these intuitions about slavery with two reminders and a distinction. I'll start with the reminders.

\subsection{Two Reminders}

1] We first need to be reminded of the formal principle of justice. This principle, attributed to Aristotle, is "treat equals equally, unequals unequally". This idea comes up most often in discussions of distributive justice, but it in fact captures the form of justice in all of its varieties. It does this because it specifies no substantial constraints on relevant criteria of equality. Other formulations of justice specify such constraints. As such, they are not rivals to this principle, but attempts to provide more specific substantive principles of justice for appli-

11 Doerflinger also thinks that life is a more basic value than freedom. We can omit this part of his case since it is not tied to his appeal to slavery. 
cation. That is, they are offered to guide us as to how to behave in order to treat equals equally and unequals unequally. The formal principle is completely silent about this. Besides reminding ourselves of this formal principle, the real point of this discussion is to remind ourselves why it is just to treat equals equally and unequals unequally. The answer has to do with moral reasoning. If one is faced with identical people in identical situations, there is nothing to which one can point as a reason to treat the two people differently. ${ }^{12}$ More realistically, if one is dealing with people who are in similar situations and who are alike in the respects relevant to the situation and to the possible ways of treating these people, then there is nothing, no aspect of the matter at hand, which can function as a reason to treat these people differently. If one treats these people differently, one does so without reason. But what is done without reason cannot be justified, since to be "justified" means to be supported by reasons. Hence treating equals unequally is unjust because it is practically irrational: the distinction in behavior is not supported by reasons. The formal principle of justice is a version of a principle of moral reasoning: if people are alike in certain respects, then we have reason to treat them alike with regard to those respects, and no reason to treat them differently with regard to those respects.

2] The second reminder concerns the relationship between moral and non-moral properties. It is widely held that relationships of regular co-variance hold between moral and non-moral properties. This is deeply plausible: if there were no such regular co-variance, appeals to moral value would be ungrounded and arbitrary. We would be unable to offer reasons for judgments that something was good, right, etc. This view has, in the

12 More specifically, there are two sorts of problem of rationality here. When treating apparent equals unequally, one may literally have no reason for doing so, or one might have a reason but be mistaken about its weight -it might well be an insufficient reason. Sometimes we even speak of people falling under the second category as having no reason. In practice, the latter case is more likely than the former, but, since this is not central to what follows, I shall speak loosely of the individual in question as having no reason. 
twentieth century, been held by such theorists as G.E. Moore, ${ }^{13}$ W.D. Ross, ${ }^{14}$ R.M. Hare ${ }^{15}$ and Jonathan Dancy, ${ }^{16}$ among many others. Hare calls this relationship "supervenience", while Dancy thinks we can distinguish a distinct relationship he calls "resultance" from supervenience. Neither the distinction between these categories nor the detailed definitions of these technical terms is important here; it is what they share that is important for our purposes. These theorists all hold that evaluative properties are tied in a relationship of dependence to non-evaluative properties. Such dependence has two notable features. First, if two items are identical with regard to all of their non-moral properties, then they must also be identical with regard to their moral properties. Second, the evaluative properties of an object, event, or state of affairs cannot change without the nonevaluative properties also changing. This point is implied by the previous one: if we allowed non-moral properties to remain constant while the moral ones changed, then we would allow that two states of affairs, differing only in time of occurrence, could be identical in non-moral respects yet different in moral respects. ${ }^{17}$

These two reminders work together to give us a somewhat practical principle of justice. If we determine that it is just to treat someone in a certain way or to accord someone a certain sort of moral status, and if this treatment or status seems to depend upon certain, identifiable non-moral properties of that

13 G.E. Moore 1903.

${ }^{14}$ W.D. Ross 1930.

${ }^{15}$ R.M. Hare 1952.

16 J. Dancy 1993.

${ }^{17}$ Even though the manner of speaking I have adopted lends itself to realist interpretations of moral properties, one need not be committed to moral realism to be committed to the regular covariance of moral and non-moral features of a situation. As noted, this idea is part of Hare's position, yet Hare is not a moral realist. Roughly put, Hare thinks non-moral properties fill criteria or standards of moral judgments. The judgments are prescriptions, i.e., they are of the form that one ought to react in such-and-such a way. Since events identical with regard to non-moral features would satisfy such criteria in identical ways, they would be morally identical. 
individual or individual's state of affairs, then we have a guide as to how to treat other people as well. Insofar as others share the properties on which the treatment or status depends, then ceteris paribus we have reason to think that they deserve the same treatment or status as the original person. It would seem to be unjust to treat these subsequent cases differently. The ceteris paribus qualification is satisfied when there are no additional properties with regard to subsequent persons or states of affairs that seem to make these cases morally different from the original case. The unpredictability indicated here demonstrates why this principle is only somewhat practical: it cannot be applied merely in the event of repeated occurrence of the non-moral properties. Close attention must be paid to the characteristics of particular situations to ensure that, so far as we can tell, there are no other non-moral properties that change the treatment or status deserved by the subsequent person.

So much for the reminders. On to the promised distinction.

\subsection{A Distinction: Deep and Shallow Autonomy}

Dworkin and Doerflinger focus on freedom when addressing slavery and both general and particular paternalism. In bioethics, as we can see from Doerflinger's example of suicide, freedom is an issue deeply bound up with what it means to respect patient autonomy. It is now widely recognized that it is morally problematic to do things to the bodies of competent people without gaining valid consent from them. One of the widely accepted conditions of valid consent is that it must be free. Coerced consent, for example, does not provide moral justification for invading person's bodies. Valid consent would seem to need to be an expression of the patient's desire for the invasion, and perhaps also of the accordance of the proposed activity with the values that structure the patient's plans for his/her life. We have no reason to think coerced consent is of this sort. In fact, if one must force the patient to consent -i.e., if consent to the activity would not have been forthcoming without coercion - then we have good reason to think 
the particular forced consent is not an expression of the right sort.

Freedom is a condition of valid consent, and acquiring such consent is a way of respecting patient autonomy. As I have argued elsewhere, ${ }^{18}$ however, the concept "autonomy" is used in at least a couple of ways in applied ethics literature. Two senses are particularly important:

1] Making autonomous choices/decisions

2] Being an autonomous person

As the above discussion of valid consent should suggest, the applied ethics literature on autonomy often focuses on autonomous choices. Focusing on freedom is at least partly due to this emphasis. If respecting autonomy depends upon particular choices being made in the right way, and if freedom of choice seems to be important to making these decisions in the right way, then what begins as an interest in respecting autonomy can, in practice, turn into policies and practices meant to ensure free decisions. Freedom emerges from the focus on autonomous choice as a value in itself.

There are problems here. One problem should already be clear: even with regard to autonomous choice, freedom is only an instrumental value. The real value is autonomy. With the realization that the notion of autonomy is ambiguous, another problem arises. The emphasis on freedom as a value is a distortion of its role in serving autonomous choice. If autonomous choice is not the most important form of autonomy for our moral interests, then our focus on freedom may even be more distant from the heart of matters than it originally appeared. Worrying about freedom might turn out to be a focus on an ethically minor matter.

Let us call a concern with autonomous choice a concern with shallow autonomy. This is shallow because it addresses questions which, so to speak, remain on the surface of an individual's

18 A. Sneddon 2001. 
life. I shall follow Robert Arrington ${ }^{19}$ and Harry Frankfurt ${ }^{20}$ in explaining autonomous desires in terms of 1st and 2nd order mental states. A desire with some object or event, etc., as content is a lst order desire. Many of us have lst order desires for coffee: this desire has the form "I want/desire coffee". A 2nd order desire about a desire for coffee has the form "I want to want coffee". Acting on the basis of such a desire would be a fairly trivial and superficial matter. Even when such choice concerns an important topic, the sort of autonomy in question is shallow because of the way the person is engaged in the decision. In general, when I speak of autonomous choice and action, I mean choice and action yielded by this combination of 1st and 2nd order desires. ${ }^{21}$

By contrast, asking questions about the characteristics of autonomous persons is to examine deep autonomy. These concerns are much more central to the identity of individuals than mere autonomous choice, hence their depth. Autonomy is rightfully often interpreted in terms of self-rule. Self-rule, however, is poorly explained in terms of autonomous choices. Self-rule is much better handled in terms of being an autonomous person. Central to this notion is having and exercising control over one's life. This certainly seems to be a value worth respecting. More pertinent to present purposes, having and exercising control over one's life seems to be at the moral heart of medical practices of attaining consent. To have control over one's life is, at least in part, to have a life-plan. Having some sort of plan for one's life requires reflection, foresight, self-assessment, sensitivity to values that might structure a life, knowledge of the kinds of life one pursue, and perhaps other cognitive operations. Forming a life-plan - central to self-rule - is a matter of performing certain sorts of thought; choices are a distinct matter.

19 R. Arrington 1982, pp. 3-12.

20 H. Frankfurt 1971, pp. 5-20.

${ }^{21}$ For discussion, see R. Crisp 1987, pp. 413-418. 
Two sorts of thought are particularly important:

A] Thought about whether the desires we have, either 1st or 2nd order, are worth having.

B] Thought about what values one should be committed to.

The performance of [A] type deep autonomy requires reflection about one's desires that measures them against certain standards of value. Since one can have 2 nd order desires about lst order desires without performing such reflection, [A] type deep autonomy is not required to make autonomous choices. This is deeper autonomy than such choices because it requires more reflection, and the exercise of more control, over one's motivations than what I have called shallow autonomy. [B] type deep autonomy is even deeper: it requires reflection about the standards of value used in [A] type deep autonomy. Performance of this sort of thought is at the core of developing a life-plan because it requires that one pay attention to whether possible kinds of lives are worth living, and to whether possible standards of value are worth adhering to. ${ }^{22}$

In brief summary: shallow autonomy consists in choice and action yielded by lst order desires backed up by 2 nd order ones. When one acts autonomously in this sense, one does what one currently wants to want to do. Deep autonomy consists in reflection on one's desires and the structure of one's life. It concerns, minimally, deciding whether it is worth doing what one currently wants to want to do. More extensively, deep autonomy is exercised in attending to what it would be to lead a life worth living.

What is the relationship between deep and shallow autonomy, between self-rule and making autonomous choices? Clearly, they often go together: the exercise of control over the shape and direction of one's life is going to involve a series of particular

22 See Sneddon (2001) for further discussion of the kinds of thought required for deep autonomy. There I frame the discussion in terms of Charles Taylor's idea of strong evaluation. See Taylor (1985a) and (1985b), and (1989) for this idea. 
choices. But since these notions are distinct, they can come apart. This distinction implies the following four possibilities:

\begin{tabular}{|c|c|c|}
\hline Self-Rule & $\begin{array}{l}\text { Autonomous } \\
\text { Choice }\end{array}$ & Example \\
\hline 1] Yes & Yes & $\begin{array}{l}\text {-Dictating own medical treatment by } \\
\text { making own decisions. }\end{array}$ \\
\hline 2] Yes & No & $\begin{array}{l}\text {-Turning control of medical treatment } \\
\text { over to physician. }{ }^{23}\end{array}$ \\
\hline 3] No & Yes & $\begin{array}{l}\text {-Wanting to want a cup of coffee with- } \\
\text { out having reflected on whether this is } \\
\text { really worth wanting or should be part } \\
\text { of one's life. }\end{array}$ \\
\hline 4] No & No & $\begin{array}{l}\text {-Making choice not backed up by } 2 \text { nd } \\
\text { order desire or reflection on its desir- } \\
\text { ability, such as spur of the moment } \\
\text { purchase spurred by advertising which } \\
\text { one does not want to want and which } \\
\text { one has not located in a reflectively de- } \\
\text { veloped life-plan. }\end{array}$ \\
\hline
\end{tabular}

By implication, both self-rule and being an autonomous person are consistent with making particular decisions non-autonomously. Non-autonomous choice might threaten, but not necessarily fatally, self-rule. A coerced choice, e.g., can happen within the course of a life run mostly autonomously. More interestingly, one can be an autonomous person yet turn control of certain decisions or aspects of one's life over to other people. And still more interestingly, giving up of shallow autonomy might serve deep autonomy in particular cases. The second example illustrates both of these latter points, since in general good health facilitates controlling one's life, and one's best health interests can sometimes be best served by turning control of particular decisions over to medical experts.

To reiterate, the moral value of autonomy seems to consist in the idea that individuals ought to be free to rule themselves.

${ }^{23}$ See 1] B. Freedman 1975 and 2] J.F. Childress and M. Siegler 1984, pp. 17-30, for supportive discussion of this idea. 
Self-rule involves shaping and acting on a plan for one's life. The exercise of deep autonomy, then, consists in reflection on what one wants, believes, etc., and also on whether one should want, believe... these things. Acting on the basis of this sort of reflection on the shape of one's life can take the form of a series of particular autonomous choices, but it might also be realized by turning control over some domains to other people and relinquishing direct decision-making power over particular matters. Deep autonomy and shallow autonomy often work together, but they can come apart; the presence of one is not a necessary indicator of the other.

Given this last fact, a moral distinction follows: to respect shallow autonomy is not necessarily to respect deep autonomy, and vice versa. In situations where the two come apart, we might well have to choose which value to respect and aid. Such a decision will turn on our assessment of which value is more important. The answer certainly seems to be deep autonomy. Respecting someone's right to shape and direct the course of their life is clearly more important than respecting someone's right to make particular choices freely.

How then do we respect deep autonomy? The exercise of deep autonomy is primarily a matter of performing a certain sort of on-going evaluation of one's life. It is also a matter of acting in accordance with such evaluation. Hence deep autonomy is made possible by having the cognitive capacities for such thought and activity. Respecting a right to self-rule must take the form of letting people use these capacities for thought and action. At the very least, the state that is going to respect deeply autonomous beings must not do things to interfere with the sort of evaluation of oneself that constitutes the exercise of deep autonomy. ${ }^{24}$ Respecting deep autonomy takes the minimal form of allowing an individual a considerable degree of freedom in thought and, to a lesser degree, action. ${ }^{25}$

${ }^{24}$ More positive, substantive measures might be called for too, but the examination of such matters would take us too far from our present topic.

${ }^{25}$ Mill's idea, that we should be free to do what we want consistent with a similar degree of freedom of others, holds here. Untrammeled exercise of 
The idea of allowing people freedom in thought should sound both important and odd. It is important because we all know that horrible things have been done to some by others with power in the name of limiting certain sorts of thought. An emphasis on freedom of thought ought to prevent such atrocities. And yet we also all know that limiting thought is, in some respects, either impossible or at least a very difficult thing to do. The activities done in the name of limiting thought were effective in limiting action - expression of thought, action in accordance with thought - and much less effective in limiting thought itself. If ought implies can, and if it is at least practically impossible to respect freedom of thought in the name of the value of self-rule, then this prescription appears largely empty. The answer to this impression is that respecting deep autonomy takes the form of according a certain status to the individual who is capable of the appropriate sorts of thought. This status marks the individual as deserving of respect because of the capacities that make deep autonomy possible. It can also serve a protective function. We should take popular injunctions against doing certain things to people "because they're human!" as invocations of status of this sort, and perhaps as weakly articulated appeals to the status to which one is entitled due to one's capacities for the kinds of thought central to self-rule. This status is due to one's capacities, not to the actual performance of such thought and action. We can assess such capacities through reference to one's physical structure: anyone who appears to have the physical constitution of normal, mature humans can be assumed to have the capacities of normal, mature humans. Anyone who has the physical structures that ground thought should be assumed to have the capacity for thought. Hence anyone with the appropriate sort of physical structures should be accorded the status due to those

freedom in action by one can deeply compromise even the capacity for thought of others. A state interested in respecting deep autonomy must limit activities that, in certain forms, can compromise the capacity of others for the exercise of deep autonomy. 
capable of deep autonomy. They should be shown respect in the form of considerable freedom in thought and action. ${ }^{26}$

\subsection{Back To Slavery}

We started with the everyday notion that slavery is a problem of justice that has something to do with freedom. We can now put our two reminders together with the distinction between deep and shallow autonomy to clarify this. To repeat:

Reminder 1] The formal principle of justice, "treat equals equally, unequals unequally", is a principle of moral reasoning. One is behaving irrationally, i.e., without reason, if one treats people who are similar in certain respects differently with regard to those respects.

Reminder 2] Moral properties depend on non-moral ones such that no difference in moral properties can happen without a corresponding difference in non-moral properties also happening.

Distinction: "Autonomy" is ambiguously used to refer to a] making autonomous choices and b] being an autonomous person. The moral value of autonomy, supposedly addressed by medical practices of acquiring consent, seems to lie with self-rule. Selfrule is better understood in terms of being an autonomous per-

26 This is to be taken as an account of how to handle normal cases -i.e., as an account of the grounds of the status due to normal, mature persons qua rational beings. No guidance is provided here for abnormal cases. Let me suggest, minimally, that they should be handled on a case-by-case basis in a manner that is sensitive to the values here articulated for normal cases. Also, I am inclined to think that the notion of "having a capacity" should be roughly individuated, such that people who think "well" and others who think "poorly" have the same capacity: they are both capable of the kind of thought necessary for self-rule, but they perform this capacity with varying levels of success. Since having the right depends on having the capacity, not on performing the capacity well, we should see the right as shared equally by all: those who think "well" do not have a greater right to self-rule than those who think "poorly". It will often be difficult to assess marginal cases - e.g, do young adolescents have the capacity for self-rule, although they are poor at executing such capabilities, or do they lack such capacities altogether? Again, the point of the present discussion is to address clear, normal cases, so I shall not address such matters further. 
son than in terms of making autonomous choices, yet practices intended to respect autonomy tend to focus on choice.

In terms of the formal principle of justice, slavery is clearly a problem of treating equals unequally, not vice versa. We can take this to be a problem of rationality: we are doing different things to people, or according people different sorts of status, without reason. People are equal in many ways; the key to the problem of slavery consists in determining which of the ways in which slaves and non-slaves are equal is being ignored. With regard to what sort of equality are slaves and non-slaves differentially treated?

Slavery takes a variety of forms, but some sort of propertyowner relationship is central to the phenomenon as it is typically invoked by philosophers. Owners have the right, limited in particular ways and cases, to direct what happens to their property. Property has no such right. For most of the things that are property, the question of such a right makes no sense because the things lack the capacity to direct the course of their "lives". The question does make sense when we think about treating people as property, and it can clearly be seen to be central to this philosophical interpretation of being a slave. If we insisted that someone had the ultimate right to direct what happens to him/her, we could not also claim that this person was the property of another person. To fall into the class of things that are property is to be excluded from the class of things ultimately entitled to dictate the course of their own treatment.

Slave owners are purported to have the right to dictate what happens to themselves and to their property. Slaves have no such rights, at least with regard to themselves. But assigning rights in this way is to treat equals unequally. Setting and directing the course of one's life is a matter of the exercise of deep autonomy. Such autonomy requires the presence of certain sorts of cognitive capacities, which are in humans realized in certain sorts of neural structures. All normal, mature humans have the physical structures that realize the cognitive capacities through which we are deeply autonomous. For the purposes of this case, let's assume that both slave and slave-owner are mature, normal 
humans, as they often would have been in fact. This means that they both have the physical structures that ground deep autonomy. Hence to give one but not the other the right to the exercise of deep autonomy is to treat equals unequally. This is a mistake of rationality, and in practice it often takes the form of appearing to justify terribly cruel treatment. ${ }^{27}$

In accounting for the problem with slavery, we have drawn upon the first reminder and the discussion of deep autonomy. Accounting for the problem with selling oneself into slavery draws both the second reminder and shallow autonomy into the discussion. To try to sell oneself, freely, into slavery is to try to make an autonomous choice that turns one from a non-slave into a slave. Given that it seems conceptually possible that this choice could be made autonomously, and given that we generally

27 All of this presupposes that one cannot avoid attributing rights to at least one person. There are at least two ways one could argue for this idea. First, a conceptual argument:

$C A]$ The state cannot without inconsistency treat people as if they had no right to self-rule. At least one person in a state needs to be free to exercise self-rule. Given that other people will have capacities of thought equivalent to those of this person, justice and rationality demand that these others have the right to self-rule.

This argument depends on the premise that a state cannot be made completely of slaves. I suspect this is true, but I do not want to be committed to such an a priori assertion on an apparently empirical issue. So, here is a second, more robust, pragmatic argument:

$P A]$ All action inherently presents a claim to a right to such action. Such claims are inherent here, not imposed from without. Humans cannot help but interact. In the interaction characteristic of slavery, one person, $X$, acts as if $\mathrm{s} /$ he has a greater right to dictate the course of another person's ( $Y^{\prime}$ s) life than $Y$ does. But this is at least prima facie implausible. Assuming $Y$ is a normal, competent person, $Y$ has the ability to dictate the course of his/her life, and the consequences of present choices about $Y$ 's life will matter to him/her. In short, since $Y$ is capable of leading his/her life, and since s/he has to live with this life, $Y$ has a very substantial claim to having ultimate authority about how this life will go. The kind of arrangements that make a person a slave do not erode the capacities that ground this right. Hence $X$ 's action, with its inherent claim to the rightful control of $Y$, is at least prima facie pragmatically self-defeating: the characteristics of $Y$ inherently present a stronger counter-claim.

The claim, "It's my life!", will not do for explaining why rights must be presupposed. This merely invokes the right in question, without justifying the claim. 
think it is a good thing to respect autonomous choices, how can we justify prohibitions against this sort of activity?

Despite being an autonomous choice, selling oneself into slavery is to commit an unjust act with regard to oneself. Any state that allowed free entry into slavery while prohibiting coerced slavery would still condone an unjust state of affairs. The reason is the same as before: selling oneself into slavery requires denying oneself the right to dictate the course of one's life after this decision. But such a right is not attributed to individuals by arbitrary fiat. The right is grounded by the capacities for thought had by all normal, mature humans. And these capacities in turn are grounded by the presence of the physical structures that realize them. Hence the respect one is due qua capable of the exercise of deep autonomy is tied to one's physical structure, not to one's desire for the respect. To attempt to sell oneself into slavery is to attempt to change one's moral status without changing the physical structures that ground this status. Such an act ignores the regular co-variance of moral and non-moral properties. Merely to have the physical structures that make self-rule possible makes one equal in moral status to all others with the same capacities. The legal prohibition against selling oneself into slavery is justified on the same grounds of justice and rationality as the rectification of slavery in general.

Attempting to sell oneself into slavery betrays a problem in moral reasoning. It is an error to think one can change one's moral status without also changing the non-moral respects of oneself that ground this moral status. In this case, one tries by a shallowly autonomous act to give up one's right to deep autonomy, or, what amounts to the same thing, to give up one's status as deserving of respect because capable of deep autonomy. As we have seen, this would be an unjust act directed at oneself, and any state that allowed such an act would be a state that allowed deep injustice. The consequence is that, with respect to this particular split between shallow and deep autonomy, rationality and justice demand that we protect deep autonomy by limiting shallow autonomy. Justice requires the limitation of free choice in order to protect the deeper right to self-rule to 
which one is entitled merely by having a certain sort of physical structure. $^{28}$

\section{Conclusion: Paternalism and Analogies With Slavery}

Both Dworkin and Doerflinger appeal to slavery to justify various forms of paternalism. They both think that the value to be concerned about with regard to slavery is freedom, and they both think freedom can sometimes be best served through limitations on freedom itself. The present discussion of slavery shows freedom in a much different light. Instead of being a value in itself, freedom is a means to respecting autonomy. The value of autonomy is best cashed out in terms of the value of self-rule.

Free choice can be justifiably limited if it conflicts with the right to self-rule. The choice to sell oneself into slavery is exactly such a choice. Slavery, including voluntary slavery, is wrong because it is unjust, not because it infringes on the value of freedom. In general, slavery is unjust because it treats equals unequally. In particular, it treats people who have the same physical structures grounding the same sorts of cognitive capacities as having different rights regarding the exercise of those

${ }^{28}$ I have postponed discussion of the bad consequences of slavery, but they do need attention. Surely the fact that slavery has bad consequences is part of the reason it is wrong. As long as this idea is reasonably curtailed, I am happy to acknowledge it. However, it is important to recognize other facets of slavery that point away from the role of consequences:

1] If slavery is indeed a problem with justice, then there will be a problem with slavery even if a particular instantiation has good consequences. Focusing only on consequences precludes recognition of this idea.

2] Preventing further bad consequences of a particular instantiation of slavery does not remedy the whole problem, and not just because it is very difficult to unravel things already done. Instead, slavery is a deep insult because it denies a person his/her rightful status of having moral authority over his/her life. Remedying the ills actually committed need not remedy such an insult.

3] There is something deeply respectful about freeing a slave on his/her deathbed. In such a case, the effects of the action are extremely limited, confined perhaps to psychological effects on the person freed. Nevertheless, the recognition of the person's moral right to control over his/her life, even when it cannot be acted on, shows laudable respect. 
capacities. Selling oneself into slavery runs into the same problem.

The principle derived from this consideration of slavery - that free choice can be justifiably limited when it conflicts with the right to self-rule, or, in other words, that in cases of conflict, we should privilege deep autonomy over shallow autonomydiffers from that at work in the arguments from Dworkin and Doerflinger. Their positions have to be either deeply revised or entirely given up in order to do justice to the difference between deep and shallow autonomy.

\subsection{Dworkin Reconsidered}

Dworkin points to the prohibition against selling oneself into slavery as a justified limitation on freedom. He thinks the reason this is justified is freedom itself - selling oneself into slavery reduces freedom. We now, however, have reason to think that freedom is the wrong notion to emphasize. Freedom is not a deep value in itself; autonomy is. Freedom is the means by which we respect autonomy; ensuring freedom is the way we respect autonomy. But we use the notion of autonomy in at least two ways. The autonomous choice to sell oneself into slavery is justifiably prohibited - i.e., freedom is justifiably curtailed- in the name of deep autonomy. Deep autonomy is the capacity for self-rule. Becoming a slave takes away one's right to dictate the course of one's life. This is a more important value than freedom of choice, so it is important to privilege it in cases of conflict. Dworkin's principle has to be given up because it fails to identify the real reason some instances of paternalism are justified.

Other instances of paternalism that Dworkin thinks are justified by reference to freedom can in fact be defended in the name of deep autonomy. Stop-signs, seatbelt laws, motorcycle helmet laws, and the placing of fluoride in water are justified because they limit autonomous choice - shallow autonomy - in order to facilitate self-rule - deep autonomy. They do this by preserving health, either by preventing accidents or by preventing slow degeneration. Health-preserving measures help make deep autonomy meaningful. They do this by keeping options 
open. Poor health closes kinds of life to a person typically from without, not from within a life-plan.

A subtle but very important difference between Dworkin's principle and the principle suggested here is the light in which it holds the individual. There is good reason to think that the present principle is more respectful of individuals than Dworkin's is. By focusing on free choice, Dworkin justifies interfering with a person's conduct in the name of what is known as negative freedom. This leaves the individual without future obstacle to further free choices, but it does not address why this is important, nor point to ways to facilitate genuine autonomy. In such a situation, it can seem as if the present limitation is imposed from without, since its authority is not rooted in the individual's present situation. By contrast, the present principle emphasizes present aspects of the individual him/herself as the reason to curtail free choice on some topics. Making such a rationale explicit ties the authority of the limitation on free choice to the agent in question; it makes clear that this is not an imposition from without. Moreover, delineating the differences between shallow and deep autonomy points an individual towards increasing genuine self-rule. Dworkin's principle, even when explained to an agent, addresses matters that are relatively superficial with regard to particular lives.

\subsection{Doerflinger Reconsidered}

Dworkin's principle of paternalism has to be given up, but the spirit of his position is preserved in the present account of the problem of slavery. By contrast, Doerflinger's position has to be given up altogether. Doerflinger points to slavery to show that appeals to liberty in order to justify physician-assisted suicide and voluntary euthanasia are self-defeating. He claims that freedom, the value in question, is better served in some cases by limiting free choice than by allowing it. According to Doerflinger, such cases include killing oneself and selling oneself into slavery. We can now see that freedom is the wrong notion to emphasize. Slavery is a problem of justice. Ensuring freedom is merely the way of serving the value that is unjustly infringed 
upon by slavery - autonomy. Shallow autonomy can be justifiably limited in the name of deep autonomy; this is the reason prohibitions against selling oneself into slavery are justified.

Are suicide and voluntary euthanasia consistent with deep autonomy? Can they be a genuine, legitimate exercise of self-rule? The answer, contrary to Doerflinger, is 'yes'. One does not do anything necessarily irrational, and hence unjust, by killing oneself. Particular suicides can, of course, be undertaken for very bad reasons, but the choice itself is not necessarily irrational. Consequently, if the reasons for wanting to kill oneself are compelling - e.g., because the life one faces contains more suffering than is consistent with a life worth living by one's considered standards - then the choice to die is a consistent expression of self-rule.

The reason selling oneself into slavery poses a problem of justice is that such an act consists in trying to give up the right to self-control without altering the physical capacities that ground this right. Such an act ignores the regular co-variance of moral and non-moral properties. By contrast, suicide consists in the destruction of the grounding of the moral value of deep autonomy. The right to deep autonomy vanishes with death because the capacity for it vanishes. The value in question consists in the right to shape one's life; this is not necessarily also a duty to continue to live this life. Certainly, the capacity for devising and acting on a life-plan does not rope one into continuing this life against one's will. On the contrary, one's life-plan can legitimately include an end to one's life. ${ }^{29}$

Rejecting Doerflinger's position while insisting that Dworkin is right to think that some paternalistic measures are justified brings to light an important difference between suicide and stopsigns. Stop-signs, etc., prevent us from losing our capacities for

29 This, of course, does not mean that murderers can defend themselves by appealing to the regular co-variance between moral properties and non-moral ones. In the case of suicide, one exercises one's right to determine the course of one's life by choosing to die. In the case of murder, someone else decides that you will die. The choice is made by someone who has no legitimate right to make it. This is clearly a violation of the value of deep autonomy. 
deep autonomy accidentally. Accidents cannot be part of selfrule because they are, by definition, not part of a plan. Suicide and voluntary euthanasia, however, are not accidents. When we choose to kill ourselves, we can be doing so after deep reflection on the values that shape our lives. In this form, this act is neither necessarily irresponsible nor irrational. It is unquestionably self-rule. Stop-signs, etc., are attempts to preserve normal health, which typically serves deep autonomy. But perhaps suicide can be rational when one's health is very bad and far from normal. Determining whether it is rational will require paying close attention to the details of the particular situation. At the very least, the fact that death is consistent with the legitimate exercise of self-rule entails that we cannot paint suicide as necessarily irrational with an a priori brush.

\section{REFERENCES}

Arrington, R., 1982, "Advertising and Behavior Control", Journal of Business Ethics, 1, pp. 3-12.

Brock, D., 1992, "Voluntary Active Euthanasia", Hastings Center Report, March-April, pp. 10-22.

Callahan, D., 1992, "When Self-Determination Runs Amok", Hastings Center Report, March-April, pp. 52-55. Reprinted in Soifer 1997, pp. 409-415.

Childress, J.F. and M. Siegler, 1984, "Metaphors and Models of Doctor-Patient Relationships: Their Implications for Autonomy", Theoretical Medicine, pp. 17-30.

Crisp, R., 1987, "Persuasive Advertising, Autonomy, and the Creation of Desire", Journal of Business Ethics, 6, pp. 413-418.

Dancy, J., 1993, Moral Reasons, Blackwell Publishers, Oxford.

Doerflinger, R., 1989, “Assisted Suicide: Pro-Choice or Anti-Life?", Hastings Center Report, 19:1, Jan./Feb., suppl. 16-19. Reprinted in E.-H.W. Kluge 1999, pp. 377-383.

Dworkin, G., 1972, "Paternalism", The Monist, 56, pp. 64-84. Reprinted in R. Munson 2000, pp. 402-411.

Frankfurt, H., 1971, "Freedom of the Will and the Concept of a Person", Journal of Philosophy, LXVIII, pp. 5-20.

Freedman, B., 1975, “A Moral Theory of Consent”, Hastings Center Report, 5:4, August, pp. 32-39. 
Hare, R.M., 1952, The Language of Morals, Oxford University Press, Oxford.

Kluge, E.-H.W., 1999, Readings in Biomedical Ethics: A Canadian Focus, 2nd Edition, Prentice-Hall Canada Inc., Scarborough, Ontario.

Mill, J.S., 1947, en A. Castell (ed.), On Liberty, Harlan Davidson, Inc., Arlington Heights, Illinois.

Moore, G.E., 1903, Principia Ethica, Cambridge University Press, Cambridge.

Munson, R., 2000, Intervention and Reflection: Basic Issues in Medical Ethics, 6th Edition, Wadsworth/Thomson Learning, Belmont, California.

Ross, W.D., 1930, The Right and the Good, Clarendon Press, Oxford.

Sneddon, A., 2001, "Advertising and Deep Autonomy", Journal of Business Ethics, vol. 33, no. 1 (september), pp. 15-28.

Soifer, E., 1997, Ethical Issues, Broadview Press, Peterborough, Ontario.

Taylor, C., 1989, Sources of the Self: The Making of the Modern Identity, Harvard University Press, Cambridge, Massachusetts.

- 1985a, "Self-Interpreting Animals", in Human Agency and Language Philosophical Papers, 1, Cambridge University Press, Cambridge.

—, 1985b, "What is Human Agency?", in Human Agency and Language, Philosophical Papers, 1, Cambridge University Press, Cambridge.

Received January 26, 2001; revised June 22, 2001; accepted July 4, 2001 